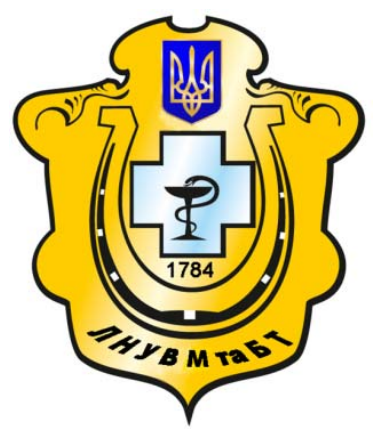

Науковий вісник Львівського національного університету ветеринарної медицини та біотехнологій імені С.3. Гжицького

Scientific Messenger of Lviv National University of Veterinary Medicine and Biotechnologies named after S.Z. Gzhytskyj

doi:10.15421/nvlvet7329

ISSN 2518-7554 print

ISSN 2518-1327 online

$\underline{\text { http://nvlvet.com.ua/ }}$

УДК 619:616.98:579.869.2(477.74)

\title{
Фазові етапи та структура кіл епізоотичної циркуляції збудника бешихи в умовах степової зони північного Причорномор'я
}

\author{
Л.В. Пероцька \\ perotskaya@ukr.net \\ Одеський державний аграрний університет, \\ вул. Пантелеймонівська, 13, м. Одеса, 65012, Украӥна
}

\begin{abstract}
Збудник бешихи є типовим бактеріальним збудником сапрозоонозної природи, який в умовах сучасного агроландшафту успішно сформував і стійко підтримує полігостальні антропургічні осередки зміманого (природно-синантропічного) та фермського типу. Враховуючи суттєві відмінності у генезисі, етіології та структурі усіх иих осередків, реалії їх розташування, активності та специффіки функиіонування постійно входять в протиріччя щчодо загальновідомих принципів та закономірностей, характерних для більшості природно-осередкових зоонозів. Метою наших досліджень було встановлення первинних еколого-епізоотичних чинників, які забезпечують фазові та поетапні зміни активності локальних осередків (антропургічного типу) бешихи. Основні матеріали для проведення аналітичних узагальнень були накопичені при дослідженнях осередків бешихи різних екотипів у 2009-2015 рр. Всі фактичні дані були піддані стандартній статистичній обробиі з використанням методик пакету програм блоку «Statistica» в системі «Exel-2012». Узагальнені результати аналізу даних щодо динаміки шільності польових гризунів (без їх видової деталізаиії) та результати їх бактеріологічного контролю заперечують існування прямої залежності в системі «численність гризунів - активність інфекції», демонструючи більш ускладнену (багатофакторну) сутність природних закономірностей спонтанного епізоотичного процесу иієї інфекції. Встановлена ензоотичність для інтразональних територій плавнів та річкових заплав, де природні кола циркуляиії бешихи підтримуються уніфікованим комплексом природно-грунтових умов та вузькогостальним резервуаром - угрупованням теплокровних хазяїв із екологічно, стаціально та етологічно схожими характеристиками. Встановлено, що головними хазяями польових штамів E.іnsidiosа можна вважати сіру полівку (без таксономічної деталізачіі) та екзантропних мишей хатніх. Найбільші обсяги висіву збудника мали місче восени на фоні найвищої численності популяцій (із високим вмістом молодняку). Навесні обсяги обліку гризунів та обсяги ізоляції від них культур E.insidiosa помітно менші, що, можливо, зумовлено загибеллю основної маси носї̈в взимку.

Ключові слова: сапрозооноз, природно-осередковий зооноз, гостальний, полігостальний, генотип, фенотип, антропургічний, агроландмафт, екзантропний, ензоотичність, E.insidiosa.
\end{abstract}

\section{Фазовые этапы и структура кругов эпизоотической циркуляции возбудителя рожи в условиях степной зоны южного Причерноморья}

\author{
Л.В. Пероцкая \\ perotskaya@ukr.net
}

Одесский государственный аграрный университет,

ул. Пантелеймоновская, 13, г. Одесса, 65012, Украина

\begin{abstract}
Возбудитель рожи является типичным бактериальным возбудителем сапрозоонозной природы, который в условиях современного агроландшафта успешно сформировал и устойчиво поддерживает полигостальные антропоргические очаги смешанного (природно-синантропического) и фермерского типа. Учитывая значительные отличия в генезисе, этиологии и структуре всех этих очагов, реалии их расположения, активности и специфики функционирования постоянно входят в
\end{abstract}

Citation:

Perotskaya, L.V. (2017). Phase stages and circle structure of epizootic circulation of erysipelas of swine in the conditions of southern Prychernomorye steppe zone. Scientific Messenger LNUVMBT named after S.Z. Gzhytskyj, 19(73), 140-144. 
противоречия относительно общечзвестных приниипов и закономерностей, характерных для больиинства природноочаговых зоонозов. Целью наших исследований было определение первичных эколого-эпизоотических причин, которые обеспечивают фазовые и поэтапные изменения активности локальных очагов (антропургического типа) рожи. Основные материаль для проведения аналитических обобщений были накоплены при исследовании очагов рожи разных экотипов в 2009-2015 г2. Все фактические данные были подвергнуты стандартной статистической обработке с использованием методик пакета программ блока «Statistica» в системе «Exel-2012». Обобщенные результаты анализа данных динамики плотности полевых грызунов (без их видовой детализации) и результаты их бактериологического контроля отрицают существование прямой зависимости в системе «численность грызунов - активность инфекиии», демонстрируя более сложную (многофакторную) сущность природных закономерностей спонтанного эпизоотического процесса этой инфекции. Установлена энзоотичность для интразональных территорий плавней и речных пойм, где природные круги циркуляции рожи поддерживаются унифицированным комплексом природно-грунтовых условий и узкогостальным резервуаром сообществом теплокровных хозяев с экологически, стациально и этологически похожими характеристиками. Установлено, что главными хозяевами полевых штаммов E.insidiosa можно считать серую полёвку (без таксономической детализации) и экзантропных мышей домашних. Самые большие объемы посева возбудителя имели место осенью на фоне наибольшей численности популяции (с высоким содержанием молодняка). Весной объемы учёта грызунов и объемь изоляции от них культур E.insidiosa заметно меньше, что возможно обусловлено гибелью основной массы носителей в зимний период

Ключевые слова: сапрозооноз, природно-очаговый зооноз, гостальный, полигостальньй, генотип, фенотип, антропургический, агроландиафт, экзантропный, энзоотичность, E.insidiosa.

\title{
Phase stages and circle structure of epizootic circulation of erysipelas of swine in the conditions of southern Prychernomorye steppe zone
}

\author{
L.V. Perotskaya \\ perotskaya@ukr.net
}

\author{
Odessa State Agrarian University, \\ Panteleimonovska Str., 3, Odessa 65012, Ukraine
}

\begin{abstract}
Erysipelas agent of swine is a typical bacterial agent of sapronosis nature which has successfully formed and steadily supports polyhostal antropurgic epicenters of mixed (naturally - synantropic) and farming type. Taking into consideration significant differences in the genesis, ethiology and structure of all these epicentres, realities of their arrangement, activity and specificity of functioning permanently come into contradiction concerning commonly known principles and regularity which are characteristic to most naturally epicentric zoonoses. The aim of our researches was to determine primary ecologically epizootic reasons that provide phase and stage changes of erysipelas local epicenters of activity (of antropurgic type). The main materials for analytical general conclusions that have been carried out were accumulated during the research of erysipelas epicenters of different ecotypes in 2009-2015. All factual data were subjected to standard statistical analysis with the help of software programme methods of «Statistica» block in the «Exel-2012» system. The generalized analysis results of density dynamics data of field rodents (without their species detailization) and the results of their bacteriological control deny the existence of the direct dependence in the system "rodents' number infection activity" showing more complicated (multifactorial) essence of natural regularity of spontaneous epizootic process of this infection. The enzooticity of intrazonal territories of flooded areas and river overflow lands where natural circles of erysipelas circulation is supported by the unified complex of natural ground conditions and narrow hostile reservoir - community of warm blooded hosts with ecologically, statially and etologically similar characteristics has been established. It has been found out that the main hosts field strains E.insidiosa can be considered to be a grey field mouse (without taxonomic detailization) and exantropic domestic mice. The largest amount of agent occurrences took place in autumn at a time when the number of the population is the highest (with the high level of the young). In spring the amounts of rodents' population increase and the isolation amounts of the cultures E.insidiosa from them are noticeably less which is perhaps stipulated by the death of the ultimate mass of carriers in the winter period.
\end{abstract}

Key words: sapronosis, naturally - epicentric zoonosis, hostal, polyhostal, genotype, phenotype, antropurgic, agrolandscape, exantropic, enzooticity, E.insidiosa.

\section{Вступ}

Незважаючи на значну кількість екологоепізоотичних досліджень природно-осередкових інфекційних зоонозів (Sergiev, 2000; Buharin et al., 2007), в тому числі й новітніх, детальне розуміння етапності явища спонтанної активації та наступної депресії осередків залишається відсутнім. У загальних рисах чітко простежується залежність цього процесу від щільності популяції гостального хазяїна (Beljakov, 1983), але при цьому майже не вивчені закономірності модифікаційних (фенотипових) варіацій та механізм заміни генотипово відмінних штамів. Особливо проблемними у даному спектрі $\epsilon$ питання екологозабезпеченої причинності пульсації активності осере- дків сапронозних і сапрозоонозних інфекцій (Buharin and Litvin, 1997), із числа яких у смузі причорноморських степів важливе значення зберігають різнотипові кола ензоотичної циркуляції Erysipelothrix rhusiopathiae (E. insidiosa).

Збудник бешихи $є$ типовим бактеріальним збудником сапрозоонозної природи, який в умовах сучасного агроландшафту успішно сформував і стійко підтримує полігостальні антропургічні осередки змішаного (природно-синантропічного) та фермерського типу. Враховуючи суттєві відмінності у генезисі, етіології та структурі усіх цих осередків, реалії їх розташування, активності та специфіки функціонування постійно входять в протиріччя щодо загальновідомих принципів та закономірностей, характерних для більшості 
природно-осередкових зоонозів. Головною причиною цих протиріч $є$ відсутність критеріїв оцінки стану первинного осередку, сформованого сапрофітним збудником, до того ж ускладненого його залежністю від впливу численних локальних факторів (Sergiev, 2000; Nakonechnij, 2007). Відповідно метою наших досліджень $є$ встановлення первинних екологоепізоотичних чинників, які забезпечують фазові та поетапні зміни активності локальних осередків (антропургічного типу) бешихи. Визначення та деталізація вказаних чинників базовані на порівняльному аналізі основних епізоотичних показників фермерських осередків, функціонуючих в умовах сучасного мозаїчного агроландшафту на території аридностепової зони Одеської та Миколаївської областей. При цьому головним завданням є оцінка рівня залежності фазового стану епізоотичного процесу в антропургічних (фермерського типу) осередках із різним віковим складом свиней та різною технологією їх утримання.

\section{Матеріал та методи досліджень}

Основні матеріали для проведення аналітичних узагальнень були накопичені при дослідженнях осередків бешихи різних екотипів за період з 2009 до 2015 років. Дослідження при цьому носили комплексний характер, що зумовило необхідність використан- ня різноманітних - загально-біологічних і спеціальних наукових методів досліджень. Специфіка даної роботи, що була спрямована на розкриття міжелементних взаємозв'язків у різнотипових осередках бешихи, передбачала поєднання лабораторних експертиз різного матеріалу з методами польових, клінічних i патологоанатомічних досліджень.

Загалом виконані дослідження були орієнтовані на фіксацію явищ трендового рівня для встановлення досить загальних (грубих) залежностей, які в цілому не вимагають украй великих та дуже детальних вибірок, що значно спрощує первинні облікові обстеження значних за площами територій агроландшафту. Всі фактичні дані були піддані стандартній статистичній обробці 3 використанням методик пакету програм блоку «Statistica» в системі «Exel-2012».

\section{Результати та їх обговорення}

На першому етапі досліджень була поставлена задача визначення наявності та активності природних осередків бешихи в межах досліджуваної території. Для цього були використані звітні дані обласних управлінь сільського господарства i санітарноепідемічної служби Одеської та Миколаївської областей за період з 1971 року до теперішнього часу. Результати обробки даних представлені на рис.1.

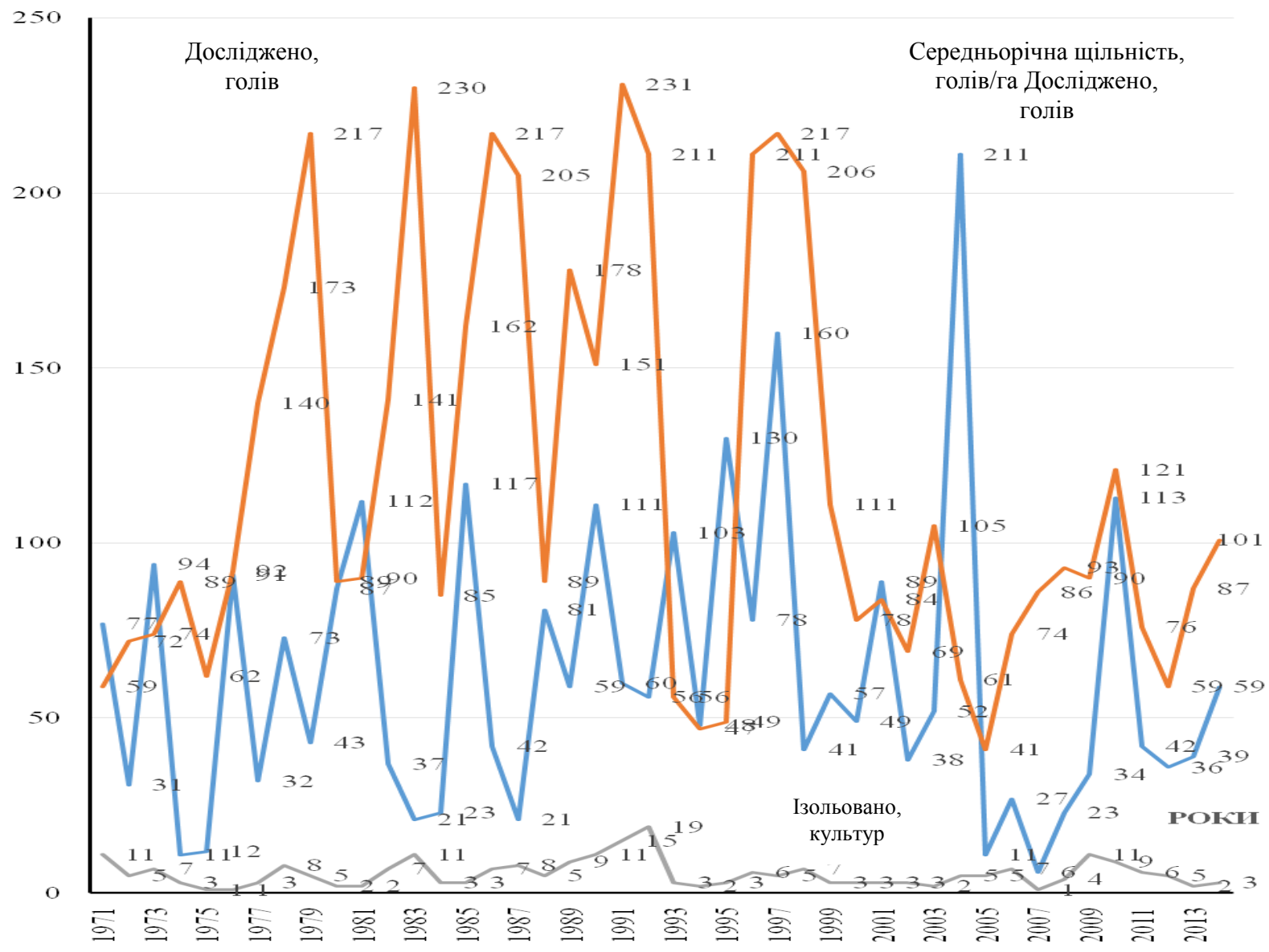

Рис. 1. Динаміка середньорічньої щільності польових гризунів, обсягів їх лабораторного контролю щодо бешихи та результатів цього контролю на сумарній території Одеської та Миколаївської областей у 1971-2014 роках 
Узагальнені результати аналізу даних щодо динаміки щільності польових гризунів (без їх видової деталізації) та результати їхнього бактеріологічного контролю (рис. 1) парадоксально заперечують існування прямої залежності в системі «численність гризунів - активність інфекції», демонструючи більш ускладнену (багатофакторну) сутність природних закономірностей спонтанного епізоотичного процесу цієї інфекції. Графічні лінії, які відображають показники щільності гризунів у полях і показники ізоляції носіїв бешихи на окремих фазових періодах існування осередків, проявляють різноспрямовані тенденції. Відповідно ці процеси, принаймні в окремих фазах, у певній мірі є самостійними.

Незважаючи на ці висновки, потрібно зазначити, що детальний аналіз вихідних даних вказує на значну помилку первинної вибірки. Остання спричинена порівнянням різнотипових кількісних показників, які не мають чіткої взаємозалежності між собою. Так, показники середньорічної щільності мишоподібних гризунів у полях є результатом екстраполяції даних агрономічної служби районних управлінь сільського господарства на всю сумарну територію обох областей. При цьому показники щільності відображають виключно стан популяцій гризунів впродовж даного року, але не враховують видову специфіку та стаціальні характеристики полів (стерня, оранка, озимина тощо), від яких прямо залежні параметри чисельності будь-якої польової біоти. У той же час звітні дані СЕС щодо результатів контролю мишоподібних гризунів відносно збудників бешихи отримані виключно при дослідженні гризунів, спійманих в плавневих і водноболотних біотопах, для яких характерна наявність лише природних кіл циркуляції штамів Erysipelothrix insidiosa (Buharin and Litvin, 1997; Shvarc, 2004). Відповідно результати порівняльного аналізу даних, отриманих різними установами з різною метою і не пов'язаних між собою єдиною еколого-епізоотичною взаємозалежністю, будуть мати лише відносний рівень достовірності та інформативності.
Таким чином, наведені дані щодо багаторічної активності кіл циркуляції збудника бешихи серед екзантропних гризунів степової зони Північно-Західного Причорномор'я не підтверджують навіть саму наявність осередків бешихи польового типу. Ензоотичність чітко підтверджена для інтразональних територій плавнів та річкових заплав, де природні кола циркуляції бешихи підтримуються уніфікованим комплексом природно-грунтових умов та вузькогостальним резервуаром - угрупованням (спільнотою) теплокровних хазяїв із екологічно, стаціально та етологічно схожими характеристиками.

3 метою чіткого визначення можливих фазових відмінностей перебігу ензоотичного процесу бешихи в осередках різних екотипів, існуючих у складі агроценозів та у складі первинних біоценозів, окремо були виконані аналітичні узагальнення власних даних щодо результатів бактеріологічного контролю польових і навколоводоймищних гризунів у 20132014 pр. (табл.1). Досліджували гризунів, спійманих і зібраних у біотопічно різних ділянках - на полях та в природних біотопах в осінній період (iз середини вересня до середини листопада) та навесні (з перших чисел березня до середини квітня). Збір матеріалу проводили переважно на території південних (прибережних) районів Одеської та Миколаївської областей, використовуючи метод трансекти. Матеріал піддавали видовій ідентифікації, потім бактеріологічному контролю в умовах районних та міжрайонних лабораторій фітосанітарної служби за стандартною методикою, але без попередньої біопроби.

Результати узагальненого аналізу даних щодо контролю гризунів із біотопічно різних ділянок мозаїчного агроландшафту вперше чітко підтвердили наявність суто польових осередків бешихи, виявлених на території трансформованих степів південних районів Північно-Західного Причорномор'я.

Табличя 1

Результати бактеріологічних досліджень стаціально різних видів гризунів на наявність збудника бешихи

\begin{tabular}{|c|c|c|c|c|c|c|c|c|c|c|c|}
\hline \multirow[b]{2}{*}{$\begin{array}{c}\text { Обсяги бактеріологічних } \\
\text { експертиз біотопічно різних } \\
\text { видів гризунів }\end{array}$} & \multicolumn{5}{|c|}{ Плавні та річкові заплави } & \multicolumn{3}{|c|}{$\begin{array}{l}\text { Відкрито-польові } \\
\text { біотопи }\end{array}$} & \multicolumn{3}{|c|}{ Разом } \\
\hline & 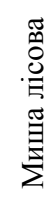 &  & 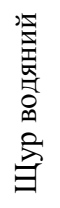 & 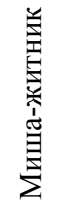 & 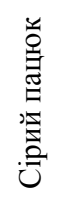 & 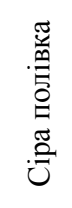 & 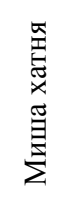 & 覓兽兽 & $\begin{array}{l}\circ \\
0 \\
0 \\
0 \\
0\end{array}$ & $0^{\circ}$ & 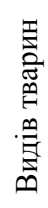 \\
\hline \multicolumn{12}{|c|}{ ВОСЕНИ } \\
\hline Досліджено, особин & 17 & 1 & 1 & 23 & 32 & 201 & 79 & 56 & 410 & 100 & 8 \\
\hline $\begin{array}{c}\text { Виділено культур збудника } \\
\text { бешихи }\end{array}$ & - & - & - & 1 & 1 & 3 & 2 & - & 7 & 1,7 & 4 \\
\hline \multirow{2}{*}{ \% висіву } & - & - & - & 4,3 & 3,1 & 1,5 & 2,5 & - & \multirow{2}{*}{-} & \multirow{2}{*}{-} & \multirow{2}{*}{ - } \\
\hline & \multicolumn{5}{|c|}{ по групі $-2,7$} & \multicolumn{3}{|c|}{ по групі - 1,5 } & & & \\
\hline \multicolumn{12}{|c|}{ HABECHI } \\
\hline Досліджено, особин & 11 & - & - & 11 & 9 & 119 & 23 & 33 & 206 & 100 & 5 \\
\hline $\begin{array}{c}\text { Виділено культур збудника } \\
\text { бешихи }\end{array}$ & 1 & - & - & 1 & - & 1 & 1 & - & 4 & 1,9 & 4 \\
\hline \multirow{2}{*}{$\begin{array}{l}\text { \% висіву в особин даного } \\
\text { виду }\end{array}$} & 9,0 & - & - & 9,0 & - & 0,8 & 4,3 & - & 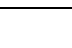 & \multirow{2}{*}{-} & \multirow[b]{2}{*}{-} \\
\hline & \multicolumn{5}{|c|}{ по групі - 6,4 } & \multicolumn{3}{|c|}{ по групі - 1,1 } & - & & \\
\hline
\end{tabular}


Незважаючи на обмеженість об'єктів контролю, головними хазяями польових штамів E. insidiosa можна вважати сіру полівку (без таксономічної деталізації) та екзантропних мишей хатніх. Про випадки ізоляції від цих ссавців ізолятів E. insidiosa існує багато даних в спеціальній літературі, але на досліджуваній території подібні випадки були невідомі. Окрім цього, культури збудника бешихи були виділені від гризунів - мешканців зволожених водойм, які є звичайним об' єктом паразитування для цих мікроорганізмів. На жаль, через обмеженість матеріалу, неможливо 3 достатнім рівнем достовірності судити про обсяги ураження гризунів у різних біотопах, а відповідно і про активність існуючих тут осередків.

В сезонному відношенні результати контролю гризунів відповідають очікуваним прогнозам найбільші обсяги висіву збудника мали місце восени на фоні найвищої чисельності популяцій (із високим вмістом молодняку). Навесні обсяги обліку гризунів та обсяги ізоляції від них культур E. insidiosa помітно менші, що, можливо, зумовлено загибеллю основної маси носіїв взимку.

Таким чином, попередні результати досліджень природних осередків бешихи, розташованих в біотопічно різних ділянках та підтримуваних різними видами гризунів, дозволили зафіксувати окремі фазові етапи циркуляції цих мікробних паразитів, що пов'язані лише із організменною ланкою їх існування (Buharin and Litvin, 1997). Певно, що прояв цієї фази циркуляції збудника є неможливим без його локальномісцевого перебування в грунтовій ланці існування, яка $є$ первинною відносно наступної - організменної. Враховуючи суто сапрозоонозну екологію представників роду Erysipelothrix, дослідження щодо фіксації їх векторної ланки існування, пов'язаної 3 переносниками, не проводили (Dunaeva, 1954).

Також невідомою лишається гостальна специфіка ізолятів E. insidiosa, виділених від гризунів. За основними антигенними i біохімічними характеристиками вони очікувано відповідають штамам групи В, але їх патогенність відносно свійських свиней не досліджена. Цілком імовірно, що ізоляти, висіяні від носіїв без ознак хвороби, не мають значного рівня вірулентності для ссавців взагалі. Тобто, наявність малопатогенних штамів E. insidiosa у польових та навколоводоймищних гризунів може бути свідченням первинної фази їх організменної циркуляції.

Подальші фази циркуляції природних штамів, які замкнені в межах даної (організменної) ланки, здатні спричинити зростання їх патогенності та вихід штаму за гостальні межі та міграцію на інші види тварин, в тому числі й на свійські. Тож порушення природних, тобто первинних біоценотичних угруповань (спільнот) або спрощення системної організації вторинних, що $є$ типовим для агроценозів і загалом для агроекосистем (Shvarc, 2004), закономірно призводить до втрати саморегуляції епізоотичного процесу та загрожує періодичним виникненням осередків бешихи в тваринництві.

\section{Висновки}

1. Результати виконаних досліджень вказують на відсутність в умовах агроландшафту ПівнічноЗахідного Причорномор'я чітко вираженої залежності активності епізоотичного процесу бешихи в природі від видової структури їхніх осередків, не підтверджуючи цим ряд теоретично прогнозованих закономірностей динамічного стану системи «паразит-хазяїн»;

2. Організменна фаза циркуляції збудника бешихи в природних умовах трансформованого степу забезпечена мишоподібними гризунами і відбувається в біотопічно різних ділянках агроландшафту, в тому числі в суто польових біотопах.

3. В агроценозах на фазову активність осередків бешихи має вплив фактор сезонної чисельності польових гризунів, тоді як у навколо водоймищних біотопах сезонна активність епізоотичної циркуляції цих збудників має більш рівномірний характер.

Перспективи подальших досліджень полягають у деталізації еколого-епізоотичних взаємозв'язків активності осередків бешихи із різними агрогенними та кліматогенними факторами.

\section{Бібліографічні посилання}

Beljakov, V.D. (1983). Problema samoreguljacii parazitarnyh sistem i mehanizm razvitija jepidemiologicheskogo processa. zhurn. Mikrobiologija. 5, 3-9 (in Russian).

Buharin, O.V., Litvin, V.Ju. (1997). Patogennye bakterii v prirodnyh ekosistemah. Ekaterinburg: ERA (in Russian).

Buharin, O.V., Lobakova, E.S., Nemceva, N.V., Cherkasov, S.V. (2007). Associativnyj simbioz. Ekaterinburg: UrO RAN (in Russian).

Instrukcija po uchetu chislennosti gryzunov dlja protivochumnyh stancij Sovetskogo Sojuza (1978). Minzdrav SSSR. 79 (in Russian).

Metodicheskie ukazanija (2005). Otlov, uchet i prognoz chislennosti melkih mlekopitajushhih i ptic $\mathrm{v}$ prirodnyh ochagah infekcij: MU 3.1.1029-01. Moskva-Dushanbe. MOZ (in Russian).

Nakonechnij, I. (2007). Epizootichni ta epidemichni aspekti prirodno-oseredkovih infekcij $\mathrm{z}$ tochki zoru sistemnih pozicij. Veterinarna medicina Ukrainy. 1, 810 (in Ukrainian)

Sergiev, V.P. (2000). Infekcionnye i parazitarnye bolezni na poroge tret'ego tysjacheletija. Problemy biomediciny na rubezhe XXI veka. M.: RAEN, 361376 (in Russian).

Shvarc, E.A. (2004). Sohranenie bioraznoobrazija: soobshhestva i jekosistemy. M.: Jekolit (in Russian).

Dunaeva, T.N. (1954). Jeksperimental'noe issledovanie tuljaremii $\mathrm{u}$ dikih zhivotnyh (gryzunov, hishhnikov i nasekomojadnyh) kak osnova izuchenija prirodnyh ochagov jetoj infekcii. Zool. Zhurnal. 33(2), 296-318 (in Russian).

Стаття надійшла до редакиії 5.03.2017 